\title{
A research station with a two-disc cutting unit for studying the cutting process of energy
}

\author{
Henryk Rode ${ }^{1, *}$ \\ ${ }^{1}$ Warsaw University of Technology, Faculty of Civil Engineering, Mechanics and Petrochemistry, \\ Institute of Mechanical Engineering, Łukasiewicza 17, 09-400 Płock, Poland
}

\begin{abstract}
The paper presents the construction of a new research station for studying the cutting process of energy plants. The station consists of 3 basic units: a truck with drive and cutting units, a frame which is a guide for the truck moving on it, and a base for placing the plant's stems. The station allows to determine the unitary energy of the cutting process for various rotary and travelling speeds of the cutting unit and for various sizes, spacing and angles of inclination of the cutting discs. It also allows to form freely the cut plants' stems' sockets.
\end{abstract}

\section{Introduction}

Depletion of energy from conventional sources and a continuous increase in energy consumption necessitates the search for new energy sources, preferably from renewable ones [1,5]. One of such sources is biomass [3].

Proper harvesting and fragmentation of energy crops have a great impact on the profitability of their production. Therefore, it is necessary to know about the processes occurring during cutting and fragmenting plants' stems, with particular emphasis on the factors that most affect the energy consumption of these processes $[2,4,12]$.

A research on the cutting process of cereals and grasses has been carried out for several years at the Institute of Mechanical Engineering at Warsaw University of Technology in Płock [13], and recently also of energy plants. Laboratory stands of pendulum and rotational construction are used for the research, where the process of axial cutting and inertial cutting of plants takes place $[7,8,9,10]$.

Due to the fact that the process of harvesting energy plants is most often carried out by a two-disc rotary unit [6], the latest research station for testing this process is equipped with such a cutting unit. It enables the measurement of the unitary energy of the cutting process of various plants for the variable construction and working parameters of the cutting unit. The unitary energy of the cutting process is the total energy needed to carry out the cutting process related to the cross-section area of the stems of the cut plants.

\footnotetext{
* Corresponding author: henryk.rode@ pw.edu.pl
} 


\section{Research station - assumptions and criteria of its construction}

The new research station must pursue the process of cutting plants in conditions similar to the ones on the field. The cutting unit is to consist of two interchangeable circular saw blades installed on the truck, which travels over the frame above the plants' stems placed in a special base with handles enabling the forming of plant sockets. The energy required to carry out the cutting process is recorded by the computer card.

The new research station should meet the following criteria:

- ensure safe work during testing,

- ensure durability of cutting elements,

- enable a wide range of rotary speed regulation of the cutting unit,

- enable a wide range of travelling speed regulation of the cutting unit,

- ensure the possibility to form freely the sockets of plants' stems',

- ensure the possibility of changing the inclination angle of the discs to the base surface,

- ensure the possibility of using discs of various diameters and different axle bases,

- ensure low construction costs.

\section{Research station}

The station (Fig. 1,2) consists of three basic units: a truck with drive and cutting units (Fig.3), a frame which is a guide for the truck moving on it and a base for placing the plant's stems (Fig.5).



Fig. 1. Research station with a two-disc cutting unit for studying the energy consumption during the cutting process of energy plants [1]:1 - frame, 2 - a base for placing the samples, 3 - a truck with drive and cutting units, 4 - electric motor for the truck, 5 - disc, 6 - belt transmission, 7 - electric motor for cutting unit , 8 - frequency converters, 9 - signal converter, 10 - controlling computer with a software

The maximum rotary speed of the motor is $2890 \mathrm{rpm}$. The drive of the cutting unit is transmitted from the motor by means of a belt transmission with a V-belt, arranged in an eight figure, in order to obtain opposite rotation directions of the cutting discs. The tensioner attached to the truck's frame is responsible for the tension of the V-belt.

The other motor (Pro-Motor MS 80 1-4, three-phase with the power of 0,55 kW and maximum rotary speed of $1370 \mathrm{rpm}$ ) ensures the movement of the truck with the cutting unit (Fig.3). The feed motion is realized thanks to the angular and belt transmission. The turning moment is transferred to the shaft with wheels placed on the guide. The belt tension adjustment is made by changing the position of the motor. 


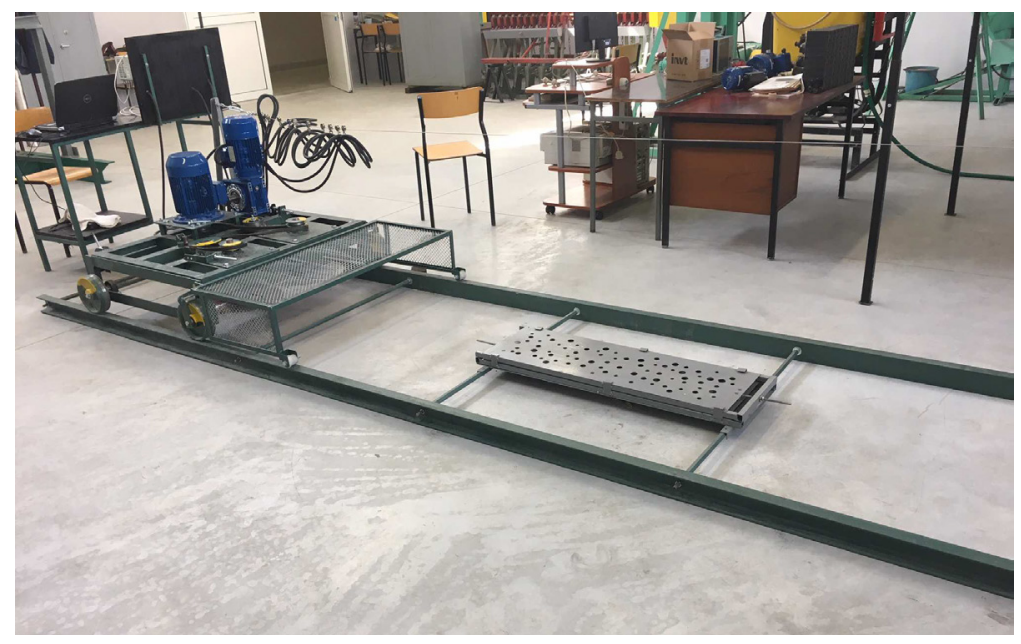

Fig. 2. Research station - view without housing

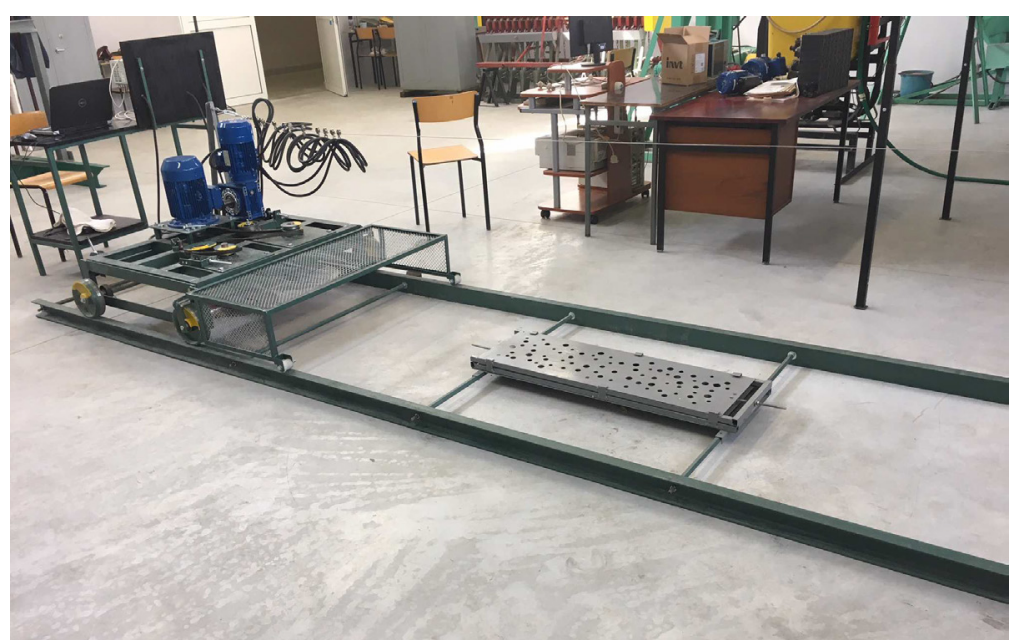

Fig. 3. A truck with drive and cutting units

For the station drives a three-phase motor, Tamel 3SK6100L-2, with rated power of $3 \mathrm{~kW}$ was used (Fig.3).

The cutting unit, used for pilot research, consists of 2 discs with an external diameter of $400 \mathrm{~mm}$ and a thickness of $2 \mathrm{~mm}$. The number of teeth of each disc is 80 (Fig.4). The axes of saw blades turn are spaced apart by $410 \mathrm{~mm}$. The adjustment of the inclination angle of the discs was carried out using screws, which are also used to tension the belt of the transmission belt responsible for the movement of the truck with the cutting unit.

Placing the plant samples takes place on a specially prepared base. It is made of two sheets of metal, in which holes with diameters from 10 to $25 \mathrm{~mm}$ were drilled randomly (Fig.5). Thanks to such a construction, plant sockets, similar to those existing in reality on the plantation, can be easily formed. Immobilization of the samples in vertical position takes place by means of shifting the sheets of metal relative to each other using screws and nuts. 


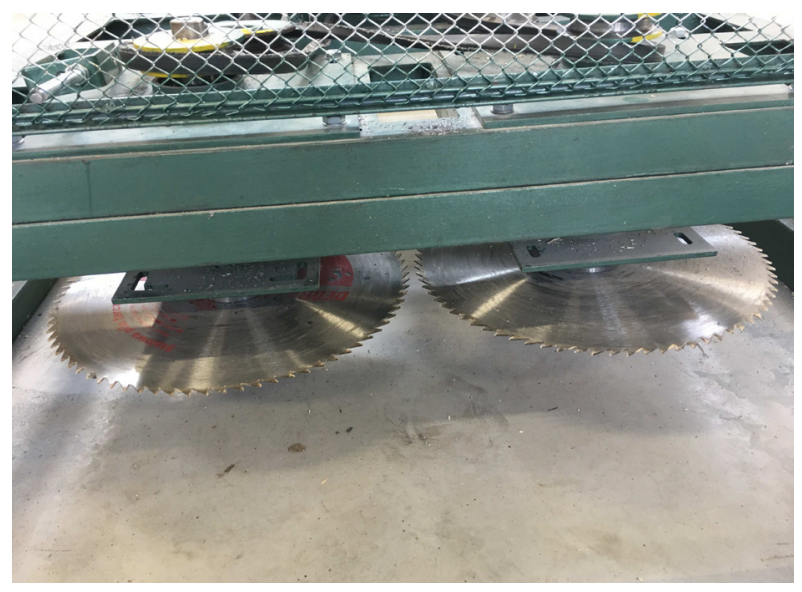

Fig. 4. Discs

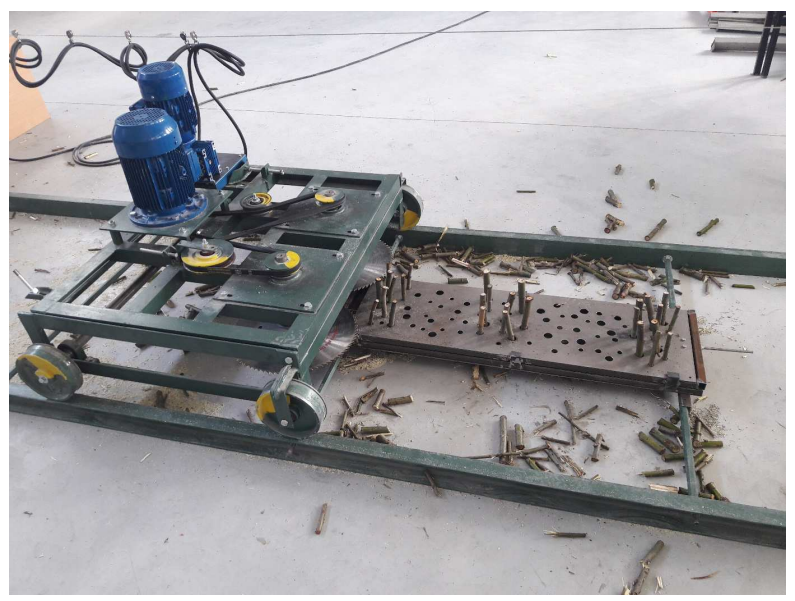

Fig. 5. A base for placing the samples

Two frequency converters LS - iG5A series are responsible for controlling the rotary speed of electric motors (Fig.6). The supply of motors and frequency converters as well as their switching on and off takes place through a fuse strip. The control of travelling speed of the truck with the cutting unit is effected by changing the frequency of the current realized by means of the frequency converter located on the left side of the control board (Fig. 6). Changing the current frequency and switching the motor on and off is effected directly from the frequency converter with the use of a special keyboard.

Rotary speed control of the cutting unit is achieved by changing the current frequency in the second converter. The ADA - I9140 signal converter and a computer with dedicated DriveView7 control software are used to record the current consumption. Using a measurement and control card, the signal from the frequency converter is downloaded to the computer. The computer records the changes in electric power consumption of the motor driving the cutting unit in time. Autodesk AutoCAD determines the area under the graph corresponding to the energy collected for the cutting process of the energy plant. The total energy obtained refers to the cross-sectional area of the samples of the stems of the cut plants, obtaining the unit energy of the cutting process.

The station is protected by a housing that protects the cut material from falling out and at the same time allows to easily take out the cut samples and place the new ones. 


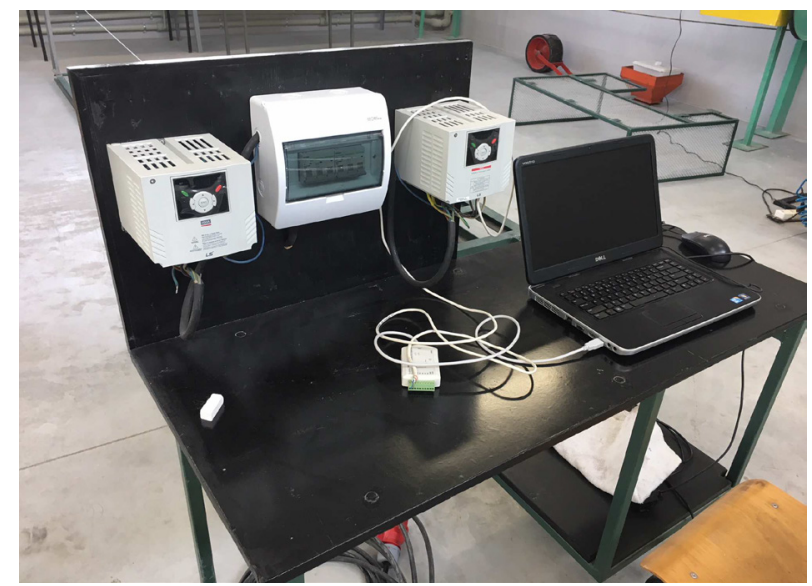

Fig. 6. Frequency converters LS - iG5A series and fuse strip

\section{Research material}

The research material for tests on the presented station are energy plants. They are characterized by a very diverse morphological structure. Their common feature is that they can be used as energy material in the form of biomass. This fuel has one feature that cannot be overestimated. The combustion process does not affect the balance of $\mathrm{CO} 2$ in the natural environment. The amount of carbon dioxide emitted to the atmosphere during the combustion of biomass is balanced by the amount of $\mathrm{CO} 2$ absorbed by the plants during its reproduction in the process of photosynthesis. The use of biomass also allows to manage biological waste.

Energy plants used for biomass production are characterized by high resistance to diseases and pests, high calorific value, small amount of carbon dioxide emitted to the atmosphere in the combustion process, high increase in dry matter in the growing season, small soil requirements, the possibility of using wasteland for cultivation, high mass density, which is extremely important during transport and storage within the boiler room. The plants are also characterized by their susceptibility to mechanization of agro technical activities related to establishing a plantation, its maintenance and biomass harvest $[3,5]$.

The group of these plants includes:

- basket willow,

- Jerusalem artichoke,

- poplars,

- Pennsylvania mallow,

- multiflorous rose,

- miskanthus giganteus,

- Sakhalin knotweed.

\section{Pilot research}

Basket willow was used as the research material in the pilot research [11]. The functioning of the station in the rotary speed range of the cutting unit from 1120 to 2400 $\mathrm{rpm}$ and the range of travelling speeds from 0.046 to $0.083 \mathrm{~m} / \mathrm{s}$ were checked. Samples with diameters of plant stems from 7 to $22 \mathrm{~mm}$ were cut. 
The study confirmed the validity of most of the assumptions. Drive units functioned correctly. The method of placing samples needs correction as the samples of plants turned out to be unstable. An additional third terminal plate should be used. The range of change of the inclination angle of the cutting discs to the base surface is worth to be increased in order to reduce the friction between the discs' surfaces and cross-cut sections of the plant stems.

\section{Conclusion}

The new research station is the most technically advanced of all stations for testing cutting process built at the Institute of Mechanical Engineering at Warsaw University of Technology in Płock. It gives the possibility to conduct a wide range of tests for variable construction and working parameters of the cutting unit as well as for variable parameters of the plant itself, e.g.: stem's diameters or moisture. The obtained results allow for a better understanding of the cutting process of energy plants carried out with a two-disc cutting unit. The research results will also enable the construction of more efficient and energysaving cutting units for agricultural machines.

\section{References}

1. Dreszer K., Michałek R., Roszkowski A., Energia odnawialna - możliwości jej pozyskiwania $i$ wykorzystania w rolnictwie, Wyd.. PTIR, Kraków - Lublin -Warszawa (2003)

2. Frączek J., Mudryk K., Metoda określenia oporów cięcia pędów wierzby energetycznej. Inżynieria Rolnicza, 8, 83, pp. 91-98, (2006)

3. Gradzik P., Grzybek A., Kowalczyk K., Kościk B., Biopaliwa, Wyd. Wieś jutra, Warszawa, (2003)

4. Kowalski S., Badania oporów cięcia wybranych roślin. Zeszyt Prob. Post. Nauk Rol. 408, pp.297- 303, (1993)

5. Lewandowski W.M., Proekologiczne odnawialne źródta energii, Wyd. NaukowoTechniczne, Warszawa (2007)

6. Lisowski A. i inni., Technologie zbiorów roślin energetycznych, Wyd. SGGW, Warszawa (2010)

7. Rode H., Witkowski P., The study of the rotary cutting process of chosen energy plants. TEKA Commission of motorization and energetics in agriculture. An international journal on motorization, vehicle operation, energy efficiency and mechanical engineering, 13, 1, Lublin - Rzeszów, , pp. 139-144, (2013)

8. Rode H., Witkowski P., Stanowisko do badań procesu cięcia roślin energetycznych. MOTROL. Commission of motorization and energetics in agriculture, An international journal on operation of farm and agri - food industry machinery, 15, 1, Lublin Rzeszów, pp. 111-114, (2013)

9. Rode H., Witkowski P., Investigations Into the Process of Rotary Mowing of Selected Energy Crops. TEKA Commission of motorization and energetics in agriculture. An international quarterly journal on motorization, vehicle operation, energy efficiency and mechanical engineering, 14, 3, Lublin - Rzeszów, pp. 95-98, (2014)

10. Rode H., Chęciński M., Research on Disc Cutting Unit for Cutting Energy Plants, TEKA Commission of motorization and energetics in agriculture, An international quarterly journal on motorization, vehicle operation, energy efficiency and mechanical engineering, 16, 1, Lublin - Rzeszów, pp. 25-30, (2016) 
11. Szczukowski S., Tworkowski J., Stolarski M.J., Wierzba energetyczna, Wyd. Plantpress Sp. z o.o., Kraków (2014)

12. Szymanek M., Analysis of cutting process of plant material, Teka Komisji Motoryzacji i Energetyki Rolnictwa - OL PAN, VIIA, Lublin, pp.107-113, (2007)

13. Żuk D. Proces cięcia źdźbet zbóż, Prace Naukowe Politechniki Warszawskiej Mechanika z. 95, Warszawa (1985) 